\title{
Crossrail project to deliver London"s Elizabeth line: from options to parliamentary bill
}

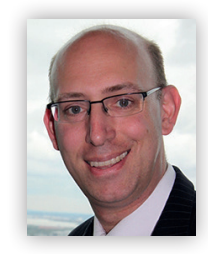

Simon Bennett BEng, FCILT, MCIPR, GMICE

Head of Learning Legacy, Crossrail Limited, London, UK

The Crossrail programme to deliver the Elizabeth line east-west railway across London, UK, was authorised by the Crossrail Act 2008. It was the culmination of 6 years of planning and development work by an organisation called Cross London Rail Links (CLRL), which was created for the purpose as a joint venture between the Strategic Rail Authority (succeeded by the Department for Transport) and Transport for London. This paper explains the planning and development work, from the creation of CLRL in 2001 until agreement was given to deposit the Crossrail parliamentary bill in 2004.

\section{Introduction}

The $£ 14.8$ billion Crossrail project to deliver the new Elizabeth line east-west railway across London, UK, has had a long and tortuous gestation. The history of the project goes back so far that it cannot be encompassed here, so this paper concentrates on the most recent and relevant history of the scheme that starts operating in 2018.

The paper covers route option selection, consultation and design development, starting from the creation of Cross London Rail Links (CLRL) in 2001 and concluding with agreement to deposit the Crossrail parliamentary bill in 2004. Information on the earlier history can be found on the Crossrail website (Crossrail, 2017) and in 'CrossRail: Scope, background and feasibility' (Fergusson, 2001).

\section{Creation of CLRL}

On 3 May 2001, Britain's transport ministers Angus Macdonald and Keith Hill announced to the houses of parliament that the UK Strategic Rail Authority (SRA) and Transport for London (TfL) would work together on project definition and design development of a new cross-London rail link. The project had been recommended by SRA's London East-West Study published in December 2000 (Figure 1) and included in the London mayor's transport strategy in 2001.

SRA and TfL then established a joint-venture company limited by guarantee, with a board and seconded staff drawn from both organisations. Staff included the 'care and maintenance' team from London Underground, which, since the original 1992 Crossrail parliamentary bill failed in 1994, had administered the safeguarding directions for Crossrail and the Chelsea-Hackney line. These had been put in place by the transport secretary to protect the routes from conflicting development.

The company was named Cross London Rail Links (CLRL) and set up offices at 1 Butler Place adjacent to TfL's headquarters at Windsor House. The first chairman of CLRL was Christopher Benson, who had long experience in property development and the City of London, and the chief executive was Norman Haste, who had led the project to build the second Severn crossing and managed the preliminary work for Heathrow Terminal 5. Two other key appointments were Jon Willis, formerly head of transport planning at TfL, as head of planning and Keith Berryman, who had led the London East-West Study work at SRA, as director of operations and development.
The remit and task given to CLRL was to define a preferred scheme for Crossrail line 1 and prepare for an authorisation process, as well as to study possible routes for a Crossrail line 2 . A sum of $£ 154$ million was allocated for this work, with the authorisation process expected to begin in late 2003. An outline 'earliest practical' timetable (Figure 2) was included in the first information brochure produced by CLRL to accompany its official launch in January 2002.

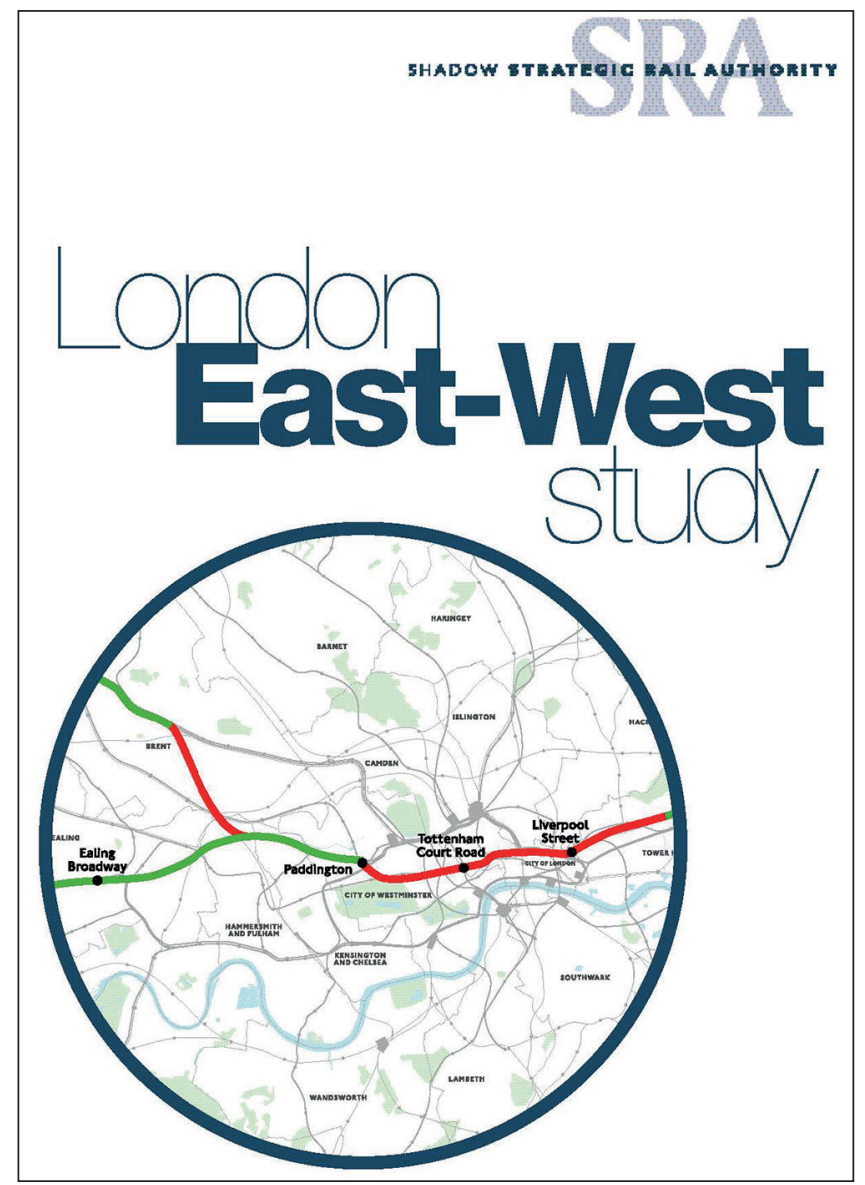

Figure 1. SRA's London East-West Study 


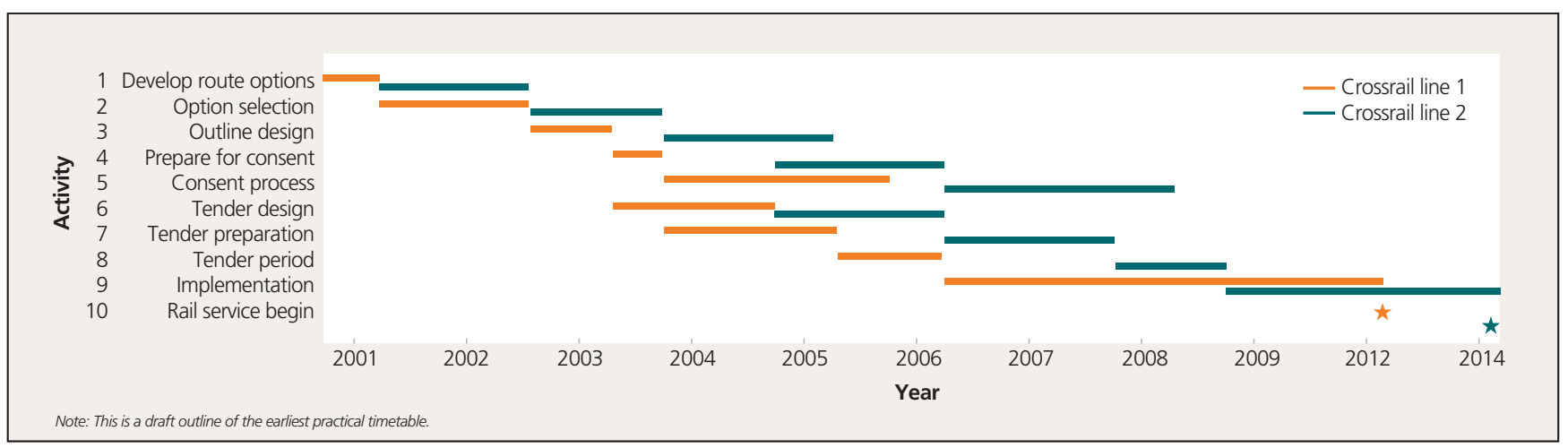

Figure 2. Outline activity programme (from 'Crossrail means...' brochure)

\section{Route option development}

One of the findings of the London East-West Study was to confirm that there were very few practical routes for a new eastwest tunnel through the centre of London. Essentially only the routes already established by safeguarding directions for an eastwest Crossrail and the Chelsea-Hackney line in the early 1990s, or a route below and along the River Thames were practical. The latter would not offer relief to the most congested London Underground lines and presented difficult construction issues, in particular at stations, so was not recommended.

The Crossrail route safeguarded in the 1990s was for a scheme running from a point just west of Paddington station to a junction with the Great Eastern main line to the east of Liverpool Street. Stations were included at Paddington, Bond Street, Tottenham Court Road, Farringdon and Liverpool Street and sites for the surface works relating to these stations, known as 'areas of surface interest', were included in the safeguarding.

The effect of the safeguarding had been to sterilise a number of potentially valuable development sites for over 20 years. It was felt that ignoring these sites and selecting new options for demolition would create unjustified new impacts and possible opposition so it was decided at an early stage to stick as far as possible to the safeguarded alignments and station locations through the central area of London.

Since the mid-1990s the geography of London had changed somewhat, with greater development taking place to the east of the City financial district. This included significant business and residential development in the area around Canary Wharf. Providing greater capacity to cater for further growth in that area was seen as a key benefit of an east-west project. In addition, the development of the former London Underground East London line into the London Overground network had had the effect of turning Whitechapel into a significant transport hub.

As a result, the work to define a preferred scheme for line 1 concentrated on the route options outside the centre, with a tunnel extending further east than the safeguarded route, and stations at Whitechapel and Isle of Dogs being included, at least as options, in all the routes considered.

A long list of options (Figure 3) was identified through desk study using the team's planning, engineering and operational experience. These options were drawn widely so as not to miss possible opportunities. They therefore included longer distance routes (such as to Oxford in the west and to Clacton or Southend in the east) as well as options to replace existing services, which had not previously been considered in the long gestation of Crossrail (such as taking over the Metropolitan line to Uxbridge).

The long-list options were assessed using a multi-criteria assessment appropriate to the level of information that could practically be identified across such a large range of options in a short time. This provided a comparative rather than exhaustive assessment. The criteria used were

cost (operating and capital)

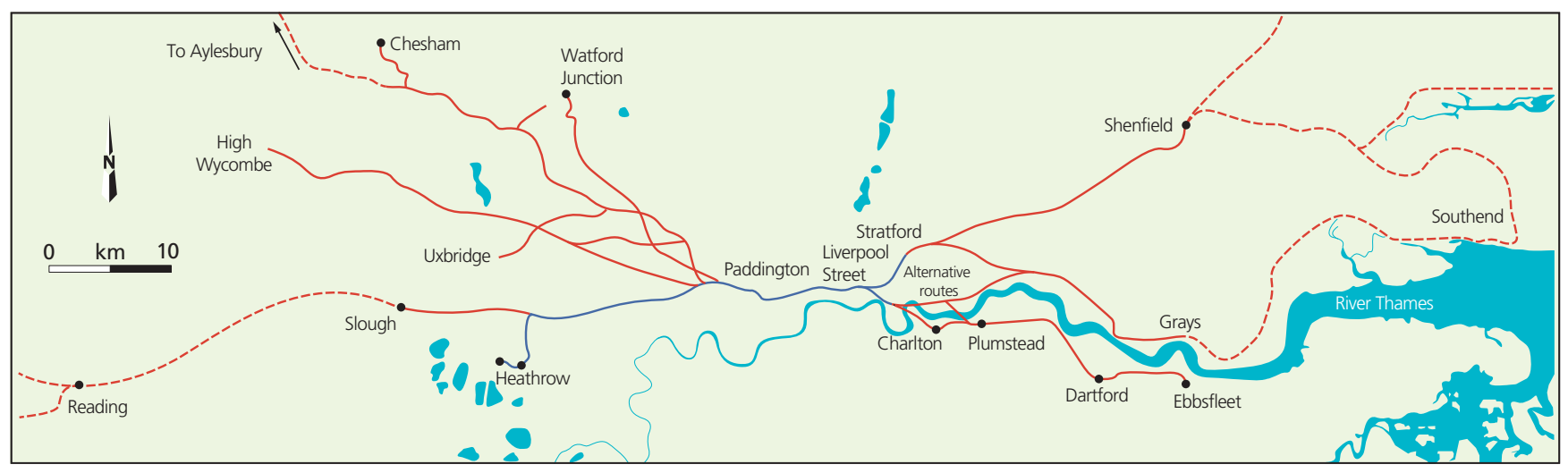

Figure 3. 2002 potential route options map (from stakeholder consultation document) 
- benefits (time savings, international connections, regeneration, social exclusion, town centre regeneration, regional access, strategic interchange, capacity, congestion relief)

- environmental impacts

- required statutory consents (railway industry and construction) - engineering and operational feasibility.

A series of reports was produced summarising the performance of groups of options to the east and west of London against these criteria. Comparing these alongside the responses from early discussions with key stakeholders, particularly railway organisations, enabled CLRL to identify a shortlist to take to a more detailed appraisal. A notable result was to confirm, as had been recommended by the London East-West Study, that Crossrail should be a metro railway, typically serving all stations on a route.

The alternative, providing a service that would run fast to the central area and then stop frequently, would be suboptimal as it would mix modes of operation and create a challenge to design a train that could cope with high passenger numbers in the centre as well as provide the expected comfort over long distances.

\section{Route option selection}

The next step was to assess the shortlisted routes using the then relatively recently introduced 'new approach to appraisal'. Alongside this, a stakeholder consultation was undertaken to seek the views of potentially affected planning authorities, but also regional government, government and non-governmental agencies as well as critical transport, planning, environment and business groups. A full public consultation was not undertaken at this stage as it would run the risk of blighting property values on routes that might not eventually be chosen. The decision was to arrive at a preferred route then consult publicly with that route as the base option.

The project published a stakeholder consultation document (CLRL, 2002) (Figure 4), including placing it on the Crossrail website where it could be viewed publicly. This led to some responses to the stakeholder consultation being received from private individuals. It is worth noting, and may be surprising to some, that the use of online media for communication was still in its infancy in the early 2000s. Modern projects need to embrace web-based communication fully, as indeed Crossrail did as it moved into the construction phase, but this includes the challenges of the expectation of instant response when using social media.

The stakeholder consultation booklet was published in May 2002 and set out five corridors for possible Crossrail services, including two alternative routes on corridor 5 between Canary Wharf and Woolwich (Figure 5). The key attributes of each route were set out in summary including commentary on the areas served, interchanges which would be provided, the impact on other services, engineering works expected to be required and the likely benefits. The document also set out the draft appraisal framework CLRL intended to use (see Supplementary Table 1), to seek views on whether it was appropriate to enable a robust decision.

A workshop was held in July 2002 to consult interested and experienced stakeholders, such as the local planning authorities, on the appraisal framework to ensure that there would be support for the decisions taken. A total of 151 responses were received to the stakeholder consultation. Mostly in the form of several-page letters, these were combined into a report that enabled the views to be considered during the workshop process to compare the options.

The appraisal framework was applied by choosing a 'reference case' project and scoring each criterion for the options as equal, better or worse than the reference case, with three levels of positivity or negativity. The reference case was essentially the widest extent of the options, with routes to Watford Junction and to Reading (and Heathrow) in the west and to Shenfield and to Ebbsfleet in the east. The route to Aylesbury via Amersham was not included in the

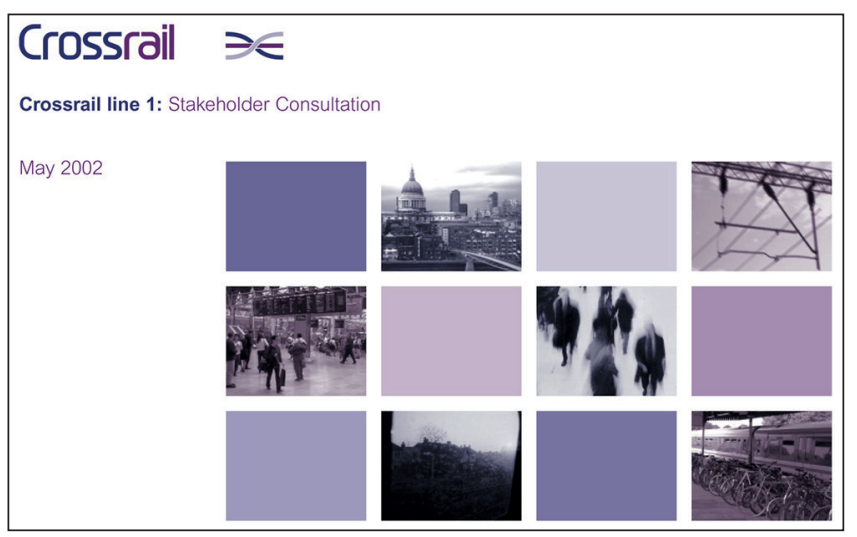

Figure 4. Stakeholder consultation document cover

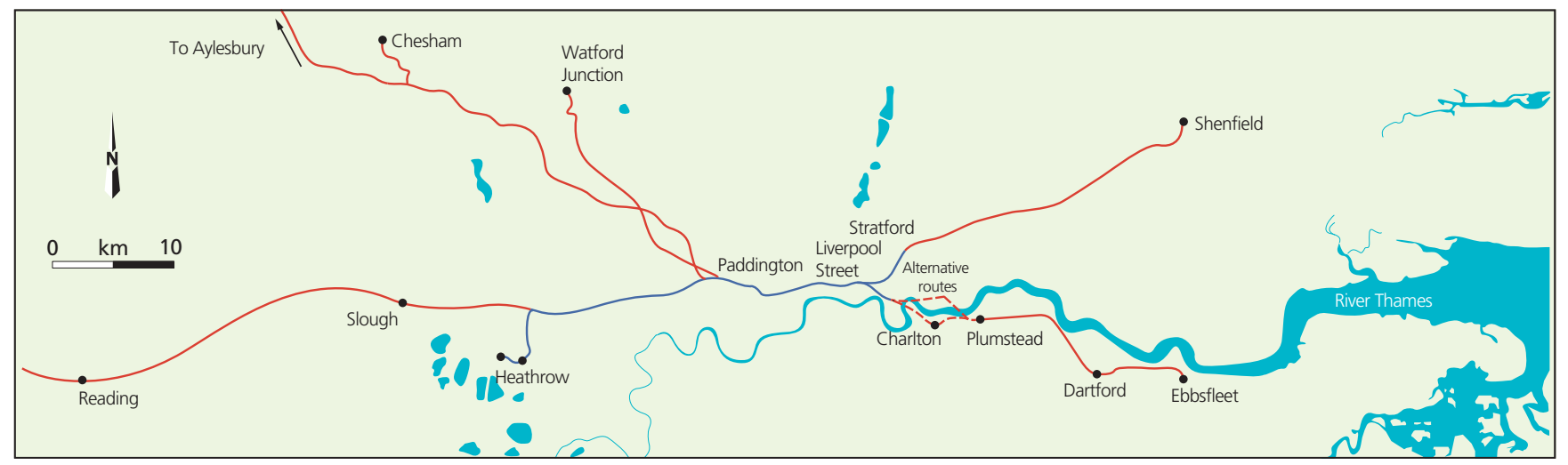

Figure 5. 2002 shortlisted corridors 
Crossrail project to deliver London's Elizabeth line: from options to parliamentary bill

Bennett reference case because there had been significant responses to the consultation from railway organisations, local authorities and others that Crossrail should avoid impacting the Chiltern line, which was performing well under a long-term franchise.

The results were presented to the Crossrail board in November 2002 with a recommendation that the reference case scheme be pursued, including stations at Whitechapel, Isle of Dogs, the Royal Docks and Woolwich. However, during 2002 the executive team at the SRA had changed and, after the board meeting, the SRA was successful in getting agreement that CLRL be instructed to consider a sixth corridor. This would be a branch serving Kingston via Richmond, connecting the Great Western main line at North Pole to the North London line north of Gunnersbury, either through a new chord at the west end of North Pole depot, or a new tunnel. The reason for this addition was to enable Crossrail to address capacity issues at Waterloo station, which had become a concern to the new team at the SRA, by attracting journeys away from stations on the South West main line.

An addendum to the consultation document was published (Figure 6) and the additional local authorities the new route would serve were consulted in January 2003 (Figure 7). The SRA also wanted to enable the Crossrail tunnel under the Thames between the North Kent line and North London line at North Woolwich to carry freight trains. This

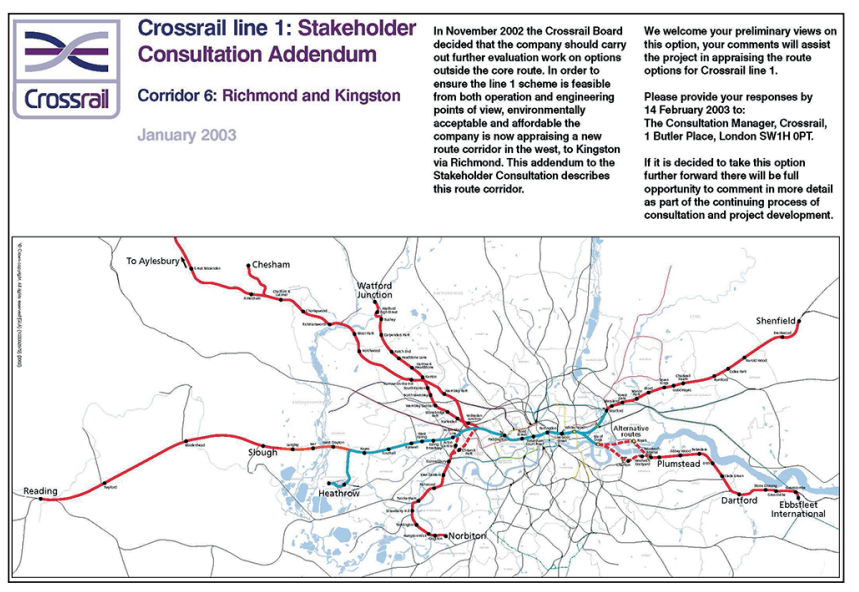

Figure 6. Corridor 6 addendum would have been incompatible with providing a below-ground Crossrail station at Woolwich due to the impact on the station environment of diesel traction and the substandard passenger platform train stepping distances required to provide clearance for container wagons. Given that the Docklands Light Railway extension to Woolwich Arsenal was about to open, providing new journey opportunities as well as additional capacity between Woolwich and central London, it was accepted by CLRL that Woolwich station be deleted.

After the additional consultation on the Kingston branch, a further comparative appraisal was performed, which produced the 2003 preferred route (Figure 8). The Watford branch was dropped, which avoided a possible issue in the days before London Overground took over the provision of services to Watford Junction on the Watford DC line. This was that the introduction of Crossrail services would have significantly reduced or even removed train services at South Hampstead and Kilburn High Road stations. The question of a surface or tunnelled route between the Great Western main line and Gunnersbury remained unresolved. This was because of the cost of the tunnel and the below-ground station at Turnham Green, and the disruption to road and rail traffic of the surface route because of level crossings. As a result these were both included as options.

\section{Preferred option consultation}

The Crossrail business case for the preferred route was presented to the Department for Transport (DfT) and this led in July 2003 to the transport secretary announcing a review of the business case and at the same time calling on CLRL to carry out public consultation. The consultation was planned to run for 12 weeks to accord with then current guidance and good practice. Crossrail set objectives for the consultation to identify and contact a wide range of stakeholders, to identify their concerns and, where practical, mitigate them.

To ensure the consultation reached as many people as possible, a public awareness campaign was held in advance to communicate the preferred route and encourage people who wished to be consulted to contact the project. To avoid the summer holidays, the awareness campaign ran from mid-September and the consultation took place from October to December 2003. By this time it had become clear that the surface route on corridor 6 was not practical and the route for consultation was therefore as shown in Figure 8.

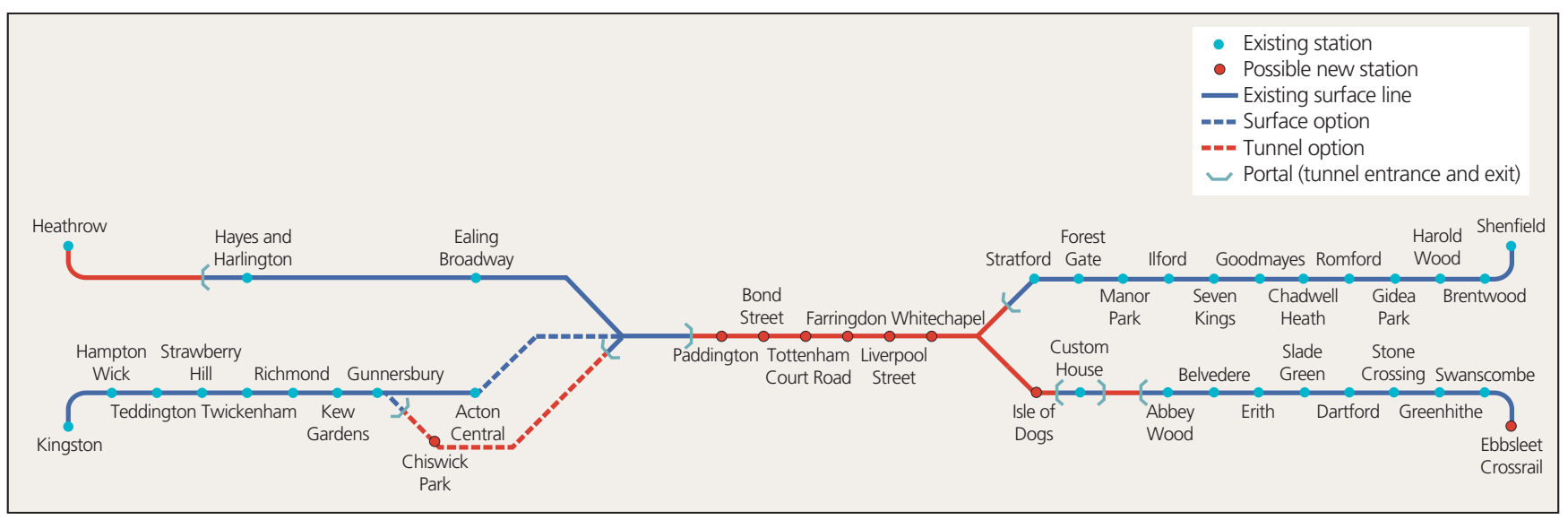

Figure 7. 2003 preferred route with corridor 6 options 


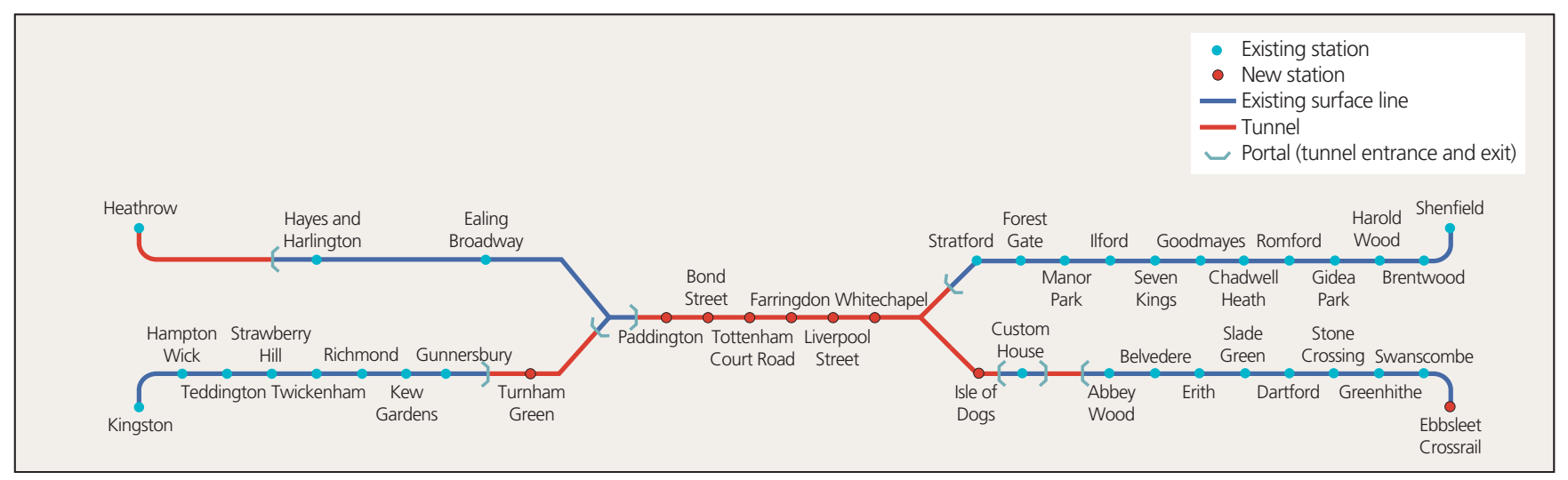

Figure 8. 2003 preferred route

The consultation programme involved holding information centres at locations along the route, close to proposed stations or significant works. The consultation team was joined at these events by engineers, planners and environment specialists from the wider CLRL team to answer detailed questions (Figure 9). Having specialists available was extremely helpful as matters of concern could be addressed directly. The team supported those experts to communicate with consultees by providing briefings to develop communication skills, ensure the scheme was understood and that likely impacts were neither under- nor over-played, and that all proposals were presented as subject to change as a result of the consultation and/or further development work.

Meetings were arranged with local authority officers, local and national politicians, and local community, business and environment groups, which had been identified from desk and web searches as well as those who responded to the initial consultation and awareness campaign.

As the publication of the route would put property at risk of blight, a major exercise was also carried out to contact all owners of land and property that might be affected by the project. Letters were sent offering a meeting with TfL property surveyors. The explanatory booklets on compulsory purchase and compensation (DCLG, 2001a, 2001b) were very useful in providing an independent explanation of the operation of the national compensation code for property to be acquired or affected. The aim was to ensure that no affected property owner would find out through visiting an information centre.

Some of the areas where concerns were raised were

- Hanbury Street, Spitalfields: construction of a shaft for ventilation, emergency escape and for launch of tunnel boring machines in an area of dense housing and narrow streets

- Richmond: construction of a dive-under to the east of Richmond station to allow Crossrail trains to access the through-Windsor line tracks to serve stations beyond Richmond to Kingston, including the acquisition of parts of back gardens adjoining the railway

- Mayfair: routing of tunnels south of Oxford Street

- Romford: construction of a depot and the need for a dive-under to access the depot that would require land from a playing field

- Shenfield: lack of benefit from the proposed services at a station where longer distance services call and, therefore, offer faster journeys to Liverpool Street than would Crossrail.

As well as the opposition to the works in these specific locations, the general concerns were noise from construction traffic, noise

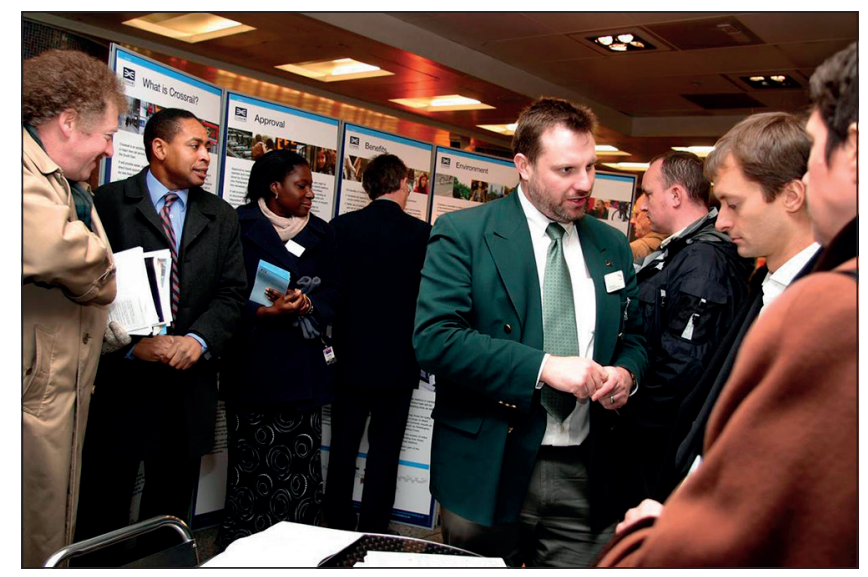

Figure 9. Crossrail staff meeting the public at an information centre

and vibration from the operation of additional trains and possible ground settlement due to tunnelling works. The Crossrail team were aware these concerns were most likely to arise and so for this consultation round the team produced a series of explanatory factsheets (Figure 10) to address the issues and explain the likely mitigation measures to be used.

The responses were reviewed and collated to identify the key issues and a report was produced, which was used by Crossrail to decide whether changes could be made. The detail of the process, results and response from the consultation is contained in an aggregated consultation report CLRL produced when the Crossrail bill was in parliament (CLRL, 2005).

\section{Review of business case}

The UK transport secretary then appointed Sir Adrian Montague, a senior civil servant, to review the Crossrail business case. His report, Crossrail Review (Montague, 2004), recommended that the project should proceed but also noted that the scheme was not an attractive proposition for a publicprivate partnership and therefore, and thanks to the receptiveness of London business representative groups, the government should consult on legislation to enable the London mayor to 
Crossrail project to deliver London's Elizabeth line: from options to parliamentary bill

Bennett

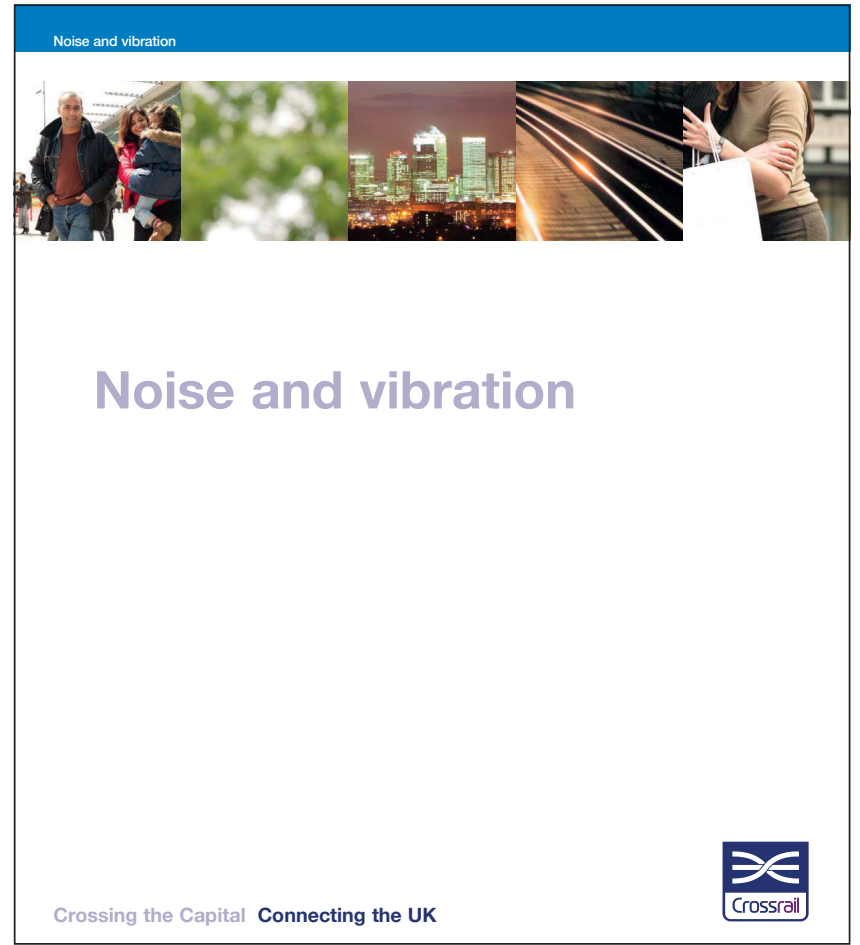

Figure 10. Example explanatory factsheet

levy businesses to provide some of the necessary funding. This ultimately bore fruit, as described in a companion paper on funding by Buck (2017).

The review also recommended that further work be done on the extent of the project. After the retirement of Benson, Montague was appointed chairman of CLRL Limited and a further round of development and consultation began with the intention of depositing a hybrid bill in November 2004.

\section{Public consultation round 2}

Revisions to the project scope recommended by the Crossrail Review (Montague, 2004) and following further work were to
- delete the route to Kingston via Richmond as the costs of the tunnel and underground station at Turnham Green were disproportionately high and the benefits low for a route that would only carry 12 trains per hour

- shorten the western route to terminate at Maidenhead, with Crossrail trains serving all stations, thus avoiding the cost of electrification between Maidenhead and Reading, a relatively long distance with only one intermediate station (electrification between Maidenhead and Reading is now being delivered for the Intercity Express programme, so services to Reading have been added to the Elizabeth line without the need for infrastructure work) (Figure 11).

A second public consultation was held, named round 2, delivered in a similar way to the first round, with some improvements. A consultation document (CLRL, 2004) (Figure 12) was produced, which summarised all the details of the proposed scheme, and set out how the scheme had changed in response to the results of round 1. The suite of factsheets was developed into a larger number of 'policy statements and position papers' modelled on documents that had been successfully used by the Channel Tunnel rail link project.

The final innovation was two fixed 'information exchanges' established in a shop unit at Farringdon station and in exhibition space in Spitalfields. Each was open for 2 days per week throughout the 12-week consultation period. More detail on the management of the consultation and the responses received can be found in the aggregated consultation report.

Responses to round 2 were more informed about the scheme. This is reflected in the fact that while the numbers of responses to each round were very similar, round 2 raised 7472 separate comments within 2836 responses, whereas round 1 had only produced 3710 issues from 2893 responses. The total number of visitors to information centres and exchanges during round 2 was 10125 , an increase on the 7244 who attended during round 1.

Alongside the consultation events, the team commissioned market research with two purposes: to check that promotion of the consultation was effective and people were aware that they could give their views, and independently to gauge support for the project. It is often difficult to understand overall reactions because those who support a scheme often do not respond to a consultation because they think it will happen whatever they say. The research found that $36 \%$ of residents within postcode areas that would be served were aware of the project. It also found that $73 \%$ agreed that the project would ease overcrowding and $64 \%$ considered it 'good value for money'.

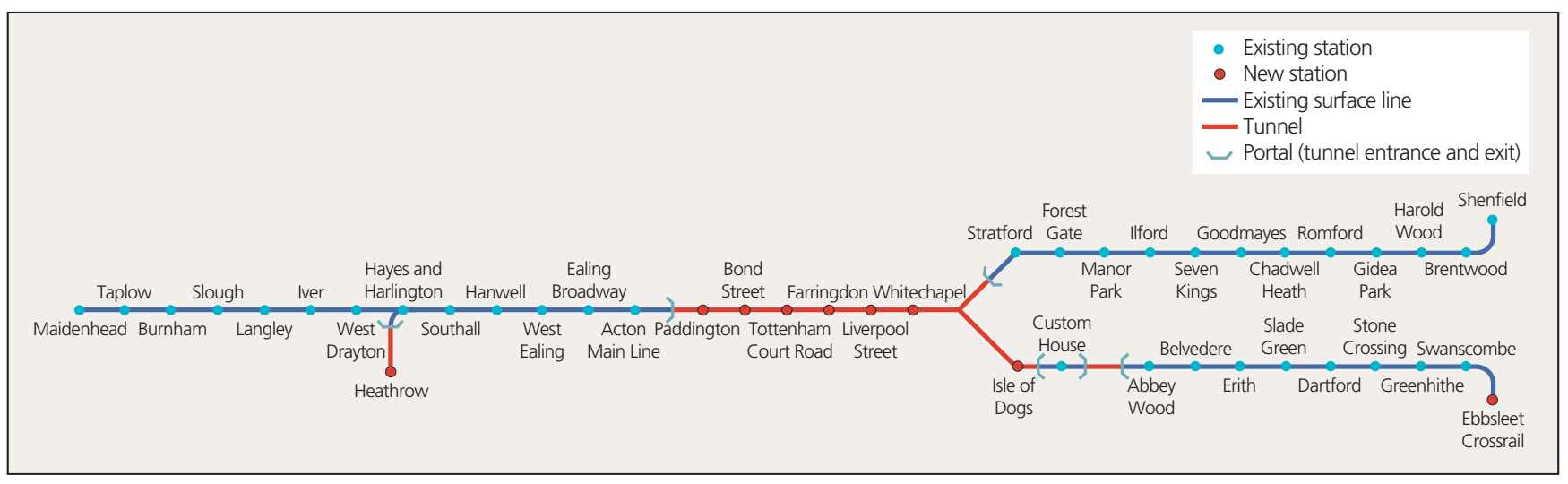

Figure 11. 2004 route 
Civil Engineering

Volume 170 Issue CE6
Crossrail project to deliver London's Elizabeth line: from options to parliamentary bill

Bennett

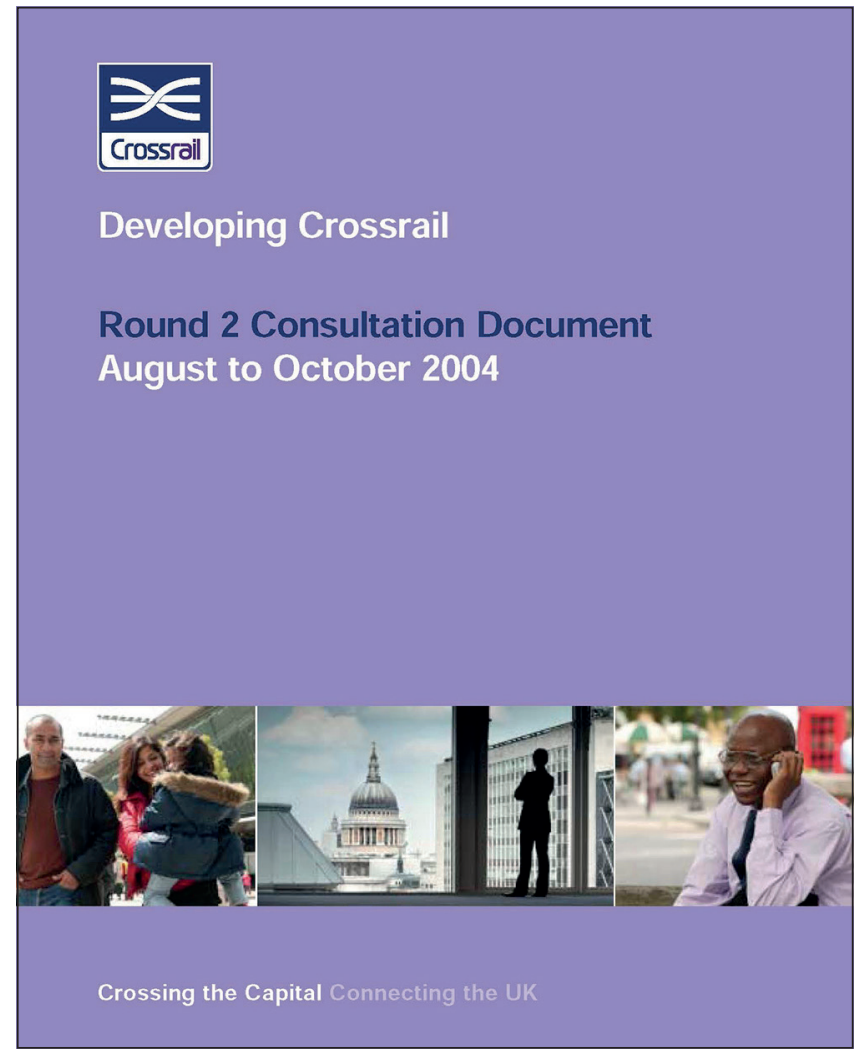

Figure 12. Round 2 consultation document

The revisions to the scheme resulting from the work recommended by the Crossrail Review and the responses to round 2 fed into the production of a new business case, on the basis of which the project was given authorisation to proceed to prepare a bill to authorise the scheme. The experiences and learnings from the bill process are the subject of a separate companion paper (Bennett, 2017)

\section{Conclusions}

While CLRL did not meet its initial aim of beginning the authorisation process in late 2003 , the reasons were not within the company's control. It is notable that several key decision points coincided with parliament rising for summer recess in the relevant year, and this demonstrates the extent to which even schemes of national significance with cross-party support are subject to external programme impacts. Future schemes could perhaps avoid this by choosing the development consent order authorisation route. This was not available to CLRL, but there are other advantages to the hybrid bill process which would need to be weighed up.

The new approach to appraisal has since been superseded by the 'Webtag' process for appraisal, but the lesson to consult on the methodology to be used with those who might challenge the results remains relevant. Keeping local authorities briefed limited the scope of their petitions to the way Crossrail would be delivered rather than what was planned. Having said that, CLRL could have been more aware of land-use planning priorities and worked more closely with local authorities; for example, to allow for further intensification of development at the new stations.

The incremental approach to consultation, while it was forced on the project by the several steps required in getting approval to proceed, worked very well to inform the public. This was demonstrated by the number of 'no comment' responses dropping considerably and the number of specific issues raised per response rising between the two consultation rounds. It was undoubtedly useful to anticipate the likely issues and field expert staff at events to ensure people's questions could be answered as immediately and fully as possible.

It would have been helpful if the full suite of information papers had been signed off between CLRL and the DfT at an earlier stage. This would have enabled more detail to be given during the consultation phase about the promoters' approach to addressing matters of concern, such as settlement, noise and vibration and property acquisition. That they were not was perhaps due to the DfT only becoming closely involved when the SRA was abolished and after the two consultation rounds had taken place.

Finally, despite the project's efforts at researching the likely petitioners, more effort could have been made to involve a wider range of consultees at the earliest stage, particularly among those who would gain from development and might therefore assist with the costs. The project assumed a non-commercial stance with consultation and, as a result, perhaps did not derive benefits for other stakeholders, which could ultimately have improved the case for the scheme. The growth of the web mentioned in Section 4 will also enable future projects more easily to identify and contact stakeholders and engage fully with them.

\section{Acknowledgements}

The author is very grateful for the assistance of Keith Berryman (director, CLRL 2001-2011), Bernard Gambrill (former head of public affairs, CLRL 2002-2006), David Taylor (head of route protection and development) and Sarah Goodburn (helpdesk manager) for providing their recollections and reviewing the author's work.

\section{References}

Bennett S (2017) Crossrail project to deliver London's Elizabeth line: the parliamentary bill process. Proceedings of the Institution of Civil Engineers Civil Engineering 170(6): 10-14, http://dx.doi.org/10.1680/jcien.17.00014.

Buck M (2017) Crossrail project: finance, funding and value capture for London's Elizabeth line. Proceedings of the Institution of Civil Engineers Civil Engineering 170(6): 15-22, http://dx.doi.org/10.1680/jcien.17.00005.

CLRL (Cross London Rail Links) (2002) Stakeholder Consultation. CLRL Ltd, London, UK.

CLRL (2004) Crossrail Business Case. CLRL Ltd, London, UK.

CLRL (2005) Aggregated Consultation Report. CLRL Ltd, London, UK.

Crossrail (2017) Crossrail - From its Early Beginnings. See www.crossrail.co.uk/ route/crossrail-from-its-early-beginnings (accessed 15/06/2017).

DCLG (Department for Communities and Local Government) (2001a) Compulsory Purchase and Compensation Booklet 1: Compulsory Purchase Procedure. DCLG, London, UK.

DCLG (2001b) Compulsory Purchase and Compensation Booklet 4: Compensation to Residential Owners and Occupiers. DCLG, London, UK.

Fergusson JC (2001) CrossRail: Scope, background and feasibility. Proceedings of the Institution of Civil Engineers - Transport 147(2): 61-69, http://dx.doi.org/10.1680/tran.2001.147.2.61.

Montague A (2004) Crossrail Review. Her Majesty's Stationery Office, London, UK. 